Review article

Section: Food Chemistry

\title{
Lemongrass (Cymbopogon citratus) Essential Oil: Extraction, Composition, Bioactivity and Uses for Food Preservation - a Review
}

\author{
Ewa Majewska*, Mariola Kozłowska, Eliza Gruczyńska-Sękowska, Dorota Kowalska, Katarzyna Tarnowska
}

\author{
Department of Chemistry, Faculty of Food Sciences, \\ Warsaw University of Life Sciences, 159C Nowoursynowska str., 02-776 Warsaw, Poland
}

Key words: lemongrass, Cymbopogon citratus, essential oils, citral, antimicrobial activity, food preservation

Lemongrass essential oil comes from the lemongrass plant (Cymbopogon citratus), which grows mainly in tropical and subtropical parts of the world. The prefix 'lemon' indicates its typical lemon-like odour, which is caused mainly by the presence of citral. Citral is a combination of two stereoisomeric monoterpene aldehydes; the trans isomer geranial is in predominance to the cis isomer neral. Lemongrass essential oil has been used since ancient times in folk medicine as a remedy to improve circulation, stabilise menstrual cycles, promote digestion or increase immunity. It is also used to produce perfumes, flavours, detergents, and pharmaceuticals. The method found to be the most suitable for the extraction of lemongrass essential oil is steam distillation, since it allows obtaining the oil without altering product quality. The chemical composition of the essential oil of $C$. citratus varies according to the geographical origin, farming practices, plant age, photoperiod, harvest period, genetic differences, and extraction methods. The chemical constituents of the essential oil which have constantly been detected and determine its biological activity are aldehydes, hydrocarbon terpenes, alcohols, ketones, and esters. The lemongrass essential oil shows a wide spectrum of biological activities. High antibacterial and remarkable antifungal activities make the lemongrass oil a potential food preservative. This paper reviews recent information on extraction methods of lemongrass essential oil, its chemical composition depending on the origin of the plant, bioactivity of the oil constituents as well as potential application as a food preservative.

\section{ABBREVIATIONS}

ADI: acceptable daily intake; BHT: butylated hydroxytoluene; DPPH: 2,2-diphenyl-1-picrylhydrazyl; GAE: gallic acid equivalents; GC: gas chromatography; GC/MS: gas chromatography coupled with mass spectrometer; HD: hydrodistillation; MAHD: microwave-assisted hydrodistillation; MIC: minimum inhibitory concentration; and SFE: supercritical fluid extraction

\section{INTRODUCTION}

In recent years, the quality and safety of food has gained a great concern among consumers, who increasingly search for healthier, nutritious, and safer food products. This tendency is reflected in research on advanced technologies for better preservation of food during production, storage and transport. For this reason, new alternatives from natural sources have been investigated such as the use of essential oils. The essential oil from Cymbopogon citratus leaves is one of the essential oils extensively studied in terms of its application as a food preservative.

C. citratus - commonly known as lemongrass - belongs to the Poaceae family which counts more than 635 gen-

\footnotetext{
* Corresponding Author: Tel.: +48 2259376 12; Fax: +48 225937635

E-mail: ewa_majewska@sggw.pl (E. Majewska)
}

era and 9000 species. This herb plant is widely distributed around the world. There are more than 140 cultivated species only for the Cymbopogon, 52 of them grow in Africa, 45 in India, 6 in Australia, 6 in South America, 4 in Europe (only in Montenegro), 2 in North America, and the others in South Asia. Cymbopogon flexuosus and Cymbopogon citratus represent the two major species vastly cultivated for their essential oils in different regions of the world. C. citratus is known by numerous international common names, such as West Indian lemon grass or lemon grass (English), citronelle or verveine des indes (French), hierba limon or zacate de limón (Spanish), xiang mao (Chinese), capimcidrao or capim-santo (Portuguese), and locally there are identified more than 28 indigenous names from different countries of the world. The genus Cymbopogon has been reviewed comprehensively in several articles [Avoseh et al., 2015; Haque et al., 2018].

C. citratus is an aromatic, evergreen, clump-forming, perennial grass producing numerous stiff stems arising from a short rhizomatous rootstock, and growing around $1.5 \mathrm{~m}$ tall. It rarely produces flowers. The leaves are blue-green in colour, flat, erect, linear in shape and give off a characteristic lemon flavour when they are crushed. C. citratus is considered to have its origin in Malaysia, nowadays it is widely cultivated in the Central and South America and parts of Africa, Southeast Asia, and the Indian Ocean Islands, both on a commercial scale and in gardens - especially in the South- 
east Asia [Skaria et al., 2012]. Lemongrass is used as a food flavouring, and can be dried and powdered, or used fresh. It is commonly used in teas, soups, and curries, it may also be served with poultry, fish, beef, and seafood. Many studies have confirmed that infusion of lemongrass leaves and other parts is highly effective in combatting various stomach infections, prevents ulcers, stimulates digestion and excretion, and is beneficial for treating nausea, stomach aches, and constipation [Carbajal et al., 1989; Leite et al., 1986]. Therefore, in many countries lemongrass is used as a medicinal herb [Avoseh et al., 2015]. In Egypt, a hot water extract of the dried leaves is taken orally as a diuretic and renal antispasmodic. In Indonesia and Malaysia, a hot water extract of the whole plant is administered orally to stimulate blood flow in the pelvic area and uterus. The Brazilians prepare a tea from the leaves of lemongrass and use it for its antispasmodic, anti-inflammatory, and analgesic effects. In Thailand, a decoction of the dried entire plant is taken orally as a remedy for stomach ache and a hot extract of dried roots is recommended for diabetes. Health benefits of lemongrass plant were reviewed comprehensively by Tapsell et al. [2006]. The biological activity of lemongrass is due to the presence of the essential oil and phenolic compounds including phenolic acids, flavonoids, and tannins [Olorunnisola et al., 2014; Roriz et al., 2014; Tavares et al., 2015]. From the nutritional point of view, lemongrass is a rich source of essential vitamins, such as: vitamin A, vitamin B1 (thiamine), vitamin B2 (riboflavin), vitamin B3 (niacin), vitamin B5 (pantothenic acid), vitamin B6 (pyridoxine), vitamin $\mathrm{C}$ and folate, along with being a host of important minerals like calcium, potassium, phosphorous, magnesium, copper, iron, and zinc [USDA National Nutrient Data Base, 2019 ].

Commercially, C. citratus is cultivated mostly for its essential oil which is biosynthesised mainly in leaves of the plant [d'Avila et al., 2016]. Lemongrass essential oil is of a considerable commercial importance because it is used in the manufacture of fragrances, flavours, perfumery, cosmetics, detergents, and pharmaceuticals. According to the Food and Drug Administration [21 CFR § 182.20, 2018], lemongrass essential oil is generally recognized as safe (GRAS) and may be used as a food additive replacing the synthetic ones. As a culinary flavouring lemongrass essential oil is added to alcoholic and non-alcoholic beverages, frozen dairy desserts, candy baked foods, gelatins and puddings, meat and meat products as well as fats and oils. It improves the flavour of some fish, wines, and sauces. Biological research has shown that various chemical compounds of lemongrass essential oil exhibit antimicrobial [Bassolé et al., 2011], antioxidant [Mansour et al., 2015], antiparasitic [Kpoviesi et al., 2014], insecticidal, and insect repellent activities [Brugger et al., 2019]. Owing to its antimicrobial and antioxidant properties, it can be exploited in food preservation as an alternative to synthetic compounds which are recently less acceptable by consumers [Ekpenyong \& Akpan, 2017].

This review article provides information on recent advances in the extraction methods of lemongrass essential oil, its composition, biological activity as well as its potential application for food preservation. The literature was carefully viewed in search for $C$. citratus essential oil data only.

\section{EXTRACTION OF LEMONGRASS ESSENTIAL OIL}

Lemongrass essential oil may be extracted by many different methods like solvent extraction, steam distillation, hydrodistillation (HD), microwave-assisted hydrodistillation (MAHD), and supercritical fluid extraction (SFE) with $\mathrm{CO}_{2}$. A number of studies have proved that the quality of essential oils depends mainly on its constituents, which is significantly influenced by the extraction techniques [Desai \& Parikh, 2015; Schaneberg \& Khan, 2002; Wu et al., 2019]. Moreover, methods involving heating may induce thermal degradation or hydrolysis of fragile constituents.

In solvent extraction, a hydrocarbon solvent (usually $n$-hexane) is added to the plant material in order to dissolve the essential oil. After filtering the solution and concentrating by distillation, a substance containing resin (resinoid) or a combination of wax and essential oil remains. The method is quite efficient for lemongrass essential oil extraction [Schaneberg \& Khan, 2002] and relatively simple but generally requires high volumes of the solvent and sometimes yields unsatisfactory reproducibility. After the extraction operation, the sample is concentrated by evaporation, during which volatiles may be reduced. Moreover, contamination of the essential oil with solvent residues may occur. The Soxhlet apparatus is sometimes used to solvent extraction of lemongrass essential oil [Alhassan et al. 2018]. In Soxhlet extraction, plant material has a continuous contact with refluxing liquid phase, which results in increased extraction efficiency. When compared to the other conventional methods, the most significant drawback of Soxhlet extraction is long heating period at high temperature (usually close to the boiling point of the solvent) which may lead to thermal degradation of fragile compounds. Both solvent extraction by maceration and Soxhlet extraction require the correct choice of the solvent to obtain a good extraction yield as well as to prevent the loss of volatiles. In recent years, the lemongrass essential oil was successfully extracted from dry and fresh lemongrass leaves using solvent extraction by Suryawanshi et al. [2016] and Alhassan et al. [2018]. The oil yield obtained by Suryawanshi group was $1.85 \%$ and that achieved by Alhassan group was $4.5 \%$. In both experiments, $n$-hexane was used as a solvent. In turn, Schaneberg \& Khan [2002] reported that sonication-assisted $n$-hexane extraction allowed obtaining lemongrass essential oil with comparable contents of the main compounds to steam distillation.

Currently, the most popular method for the extraction of the lemongrass essential oil is steam distillation. It is mainly used for temperature-sensitive materials like oils, resins, hydrocarbons, etc. which are insoluble in water and may decompose at their boiling point. It is often used to extract other essential oils as well [Fernandes et al., 2019]. In this method, steam passes through the dried or fresh plant material which softens the cells and enables the essential oil to escape in vapour form. The temperature of the steam should be high enough so that the oil could vapourize, but not so high that it damages the plant material or burns the essential oils. The released essential oil, together with steam molecules, is subsequently cooled in a condenser and collected. This process enables conducting extraction process below 
the boiling point(s) of the individual component(s). Essential oils consist of chemical compounds which boiling points often exceed $200^{\circ} \mathrm{C}$ [Berk, 2013]. In the presence of steam, these substances may be extracted at a temperature close to $100^{\circ} \mathrm{C}$, at atmospheric pressure. The basic advantage of steam distillation is simplicity, and low costs of the apparatus. The properties of the essential oil are not changed since its constituents never decompose. This technique can also be used under pressure. Lemongrass plant may be distilled fresh or after wilting. Wilting herbage before the distillation process decreases the moisture content and increases oil yield [Skaria et al., 2012]. The yields of the essential oil obtained with this method reported in the literature differ substantially, ranging from 0.24\% [Anggraeni et al., 2018], 0.3\% [Santin et al., 2009], 0.6\% [Boukhatem et al., 2014a], to 0.71\% [Kpoviessi et al., 2014]. Steam distillation is still a leading preparative technique for the extraction of lemongrass oil. A newer methodology, such as subcritical carbon dioxide extraction, although promising but expensive, has not really threatened to surpass this simple type of distillation.

In the HD technique, the plant material is totally submerged in water, which is boiled by applying direct heat. Essential oil distills together with water molecules and then is separated after condensation. The method is relatively easy and does not involve high expenses associated with the setup. The process is very slow, which may result in the degradation of some compounds in hydrolysis or polymerisation reactions of sensitive constituents due to extended heat exposure. The yield depends on various parameters such as size and weight of raw material, the nature of the herb or volume of water. A typical HD of lemongrass is conducted in a Clevenger-type apparatus for $3 \mathrm{~h}$, according to the method recommended by Guenther in 1950 [Guenther, 1950]. In recent reports, the yields of the essential oil obtained via HD range between $0.43 \%$ [Marongiu et al., 2006] and 1.80\% [Desai \& Parikh, 2015]. Ajayi et al. [2016] proved that essential oil extraction from lemongrass leaves by HD, using not only neutral but weakly acidic and basic medium, significantly affected essential oil composition. The total yield of the volatile fractions was $0.73 \%$ for HD, $0.64 \%$ for MAHD, $0.7 \%$ for acid-distillation, and $0.45 \%$ for base-distillation. The main component in the obtained essential oil was citral with the content of $72.6 \%$ for HD, $44.7 \%$ for MAHD, $30.07 \%$ for acid-distillation, and $78.61 \%$ for base-distillation. Significant differences in contents of major components (geranial, neral, myrcene) were observed as well. The low concentration of citral in the essential oil distilled in acid conditions was a result of chemical transformations of this compound that may take place in an acidic solution [Ajayi et al., 2016]. Citral contains an aldehyde moiety which can react with hydroxyl group of other terpenoids in the presence of acid molecules forming acetals. Other reactions such as polymerisation, disproportionation, cyclisation, are also likely. Basic medium provides the best environment for the extraction of lemongrass essential oil with a high citral content.

MAHD works basically the same as traditional HD, but the heating of the solvent is achieved by using microwaves. The flask containing the solvent (generally water) and the parts of the plant are placed inside a microwave oven (usually operating at $2.45 \mathrm{GHz}$ ). The use of microwaves for the heating process accelerates the extraction of oil, which can be completed in a matter of minutes, which consequently shortens time needed to obtain similar quantities of extracts. This method is very attractive to use in laboratories as well as industry due to its effective heating, fast energy transfer, and being environmentally friendly. Its acceptance as a potential and powerful alternative to conventional extraction techniques of lemongrass oil has been verified [Desai \& Parikh, 2015]. The chemical composition of the essential oils obtained with traditional HD and by MAHD does not differ substantially [Desai \& Parikh, 2015]. Significant differences may, however, be observed in contents of major components (geranial, neral, myrcene) [Desai \& Parikh, 2015]. The yields of MAHD and HD methods reported by Tran et al. [2019] were $0.35 \%$ and $0.2 \%$, respectively, the MAHD method produced oil with $93.28 \%$ while HD $83.85 \%$ with citral content.

Over the last decades, the increasing demand for high quality natural products has contributed to the development of more environmentally friendly technique of essential oils isolation, namely supercritical fluid extraction (SFE). SFE can be regarded as an alternative to the solvent extraction of various compounds from natural solid matrices without any trace of the solvent [Haloui \& Meniai, 2017]. The properties of the supercritical fluid can be modified by adjusting the critical temperature and pressure, which influences the density of the solvent allowing for selective extraction. This is particularly important for pharmaceutical and food systems. Carbon dioxide is used in most cases as the supercritical fluid due to its chemical and physical properties and to its relatively low critical temperature and pressure values (23-50 ${ }^{\circ} \mathrm{C}$ and 8-12 $\mathrm{MPa}$, respectively) [Carlson et al., 2001]. As a natural constituent of many foods, it is a non-toxic, non-corrosive, non-flammable, and inexpensive gas. It has GRAS status [21 CFR § 184.1240, 2019]. Essential oils obtained by means of this technique are of a much better quality than those obtained using solvent extraction or steam distillation and HD [Al-Marzouqi et al., 2007]. SFE with carbon dioxide can be performed at temperatures around $30^{\circ} \mathrm{C}$, thereby preserving original oil composition and properties. However, the cost of the equipment is one of the main disadvantages of this method, which restrains its use for extremely sensitive industrial sectors where high quality and purity of the final products are of the outmost priority. When it comes to the extraction of lemongrass essential oil with supercritical carbon dioxide, only few reports can be found in literature. Usually, the experiments are aimed at the optimisation of temperature and pressure of the extraction process. Carlson et al. [2001] performed supercritical $\mathrm{CO}_{2}$ extraction of fresh lemongrass leaves under different temperature and pressure conditions. They found that the composition of the essential oil significantly depended on changes in temperature and pressure parameters. The largest yields and extraction rates were determined under the conditions of $9 \mathrm{MPa}$ and $23^{\circ} \mathrm{C}$ and $12 \mathrm{MPa}$ and $40^{\circ} \mathrm{C}$, i.e. $1.7 \%$ and $1.51 \%$, respectively. The compounds recorded in larger quantities in the essential oil for all the pressure and temperature conditions applied were neral and geranial which contents ranged from $26.7 \%$ to $31.9 \%$ and from $44.6 \%$ to $53.0 \%$, respectively. Marongiu et al. 
[2006] also analysed the influence of pressure on the supercritical extraction of lemongrass oil. A series of experiments were carried out, for $360 \mathrm{~min}$, at $50^{\circ} \mathrm{C}$ and at different pressures: 9, 10, 11 and $12 \mathrm{MPa}$. Extraction conditions were selected so as to maximise citral content in the extracted oil. The collected extracts composition was compared with that of the essential oil isolated with HD and steam distillation. They determined the highest yield $(0.65 \%)$ and the highest citral content in the essential oil $(68 \%)$ at $9 \mathrm{MPa}$, while $\mathrm{HD}$ allowed achieving process yield of $0.43 \%$ and citral content of $73 \%$. The appearance of the extract was changing at higher solvent density, passing from a characteristic yellow oil to yellowish semi-solid products due to the extraction of high molecular mass compounds. Using the response surface methodology, Wu et al. [2019] predicted the optimum operational parameters of the supercritical $\mathrm{CO}_{2}$ extraction of lemongrass (C. citronella) essential oil. Under these conditions (extraction time $120 \mathrm{~min}$, pressure $25 \mathrm{MPa}$, temperature $35^{\circ} \mathrm{C}, \mathrm{CO}_{2}$ flow rate $18 \mathrm{~L} / \mathrm{h}$ ), they conducted SFE extraction with the yield of $4.4 \%$ and compared their results with these obtained using HD. The main components of the essential oil extracted with SFE and HD were geranial (20.02\% for SFE and $15.12 \%$ for HD), geraniol (10.22\% for SFE and 25.45\% for HD), and neral (15.11 for SFE and 11.15 for HD). Although, the experiment was carried out for different species of lemongrass, it was proved that the supercritical fluid did not alter the main effective components in lemongrass essential oil.

A greener approach to the extraction of lemongrass essential oil was proposed by Yen \& Lin [2017] who utilised solar energy for the extraction process. The yield of the solar energy extraction (1.28\%) was comparable with the yield of the essential oil obtained with HD (1.3\%) but the essential oil extracted by solar energy showed a higher antioxidant activity than that obtained with HD. This new technique may hold promise as a potent completely sustainable green extraction method in future.

\section{COMPOSITION OF LEMONGRASS ESSENTIAL OIL}

Lemongrass essential oil is mainly produced by leaves which contain about $1-2 \%$ of essential oil in a dry matter [Skaria et al., 2012]. The essential oil is accumulated by plant in specific oil cells of the parenchyma tissues [Ganjewala \& Luthra 2010]. The characteristic feature of lemongrass essential oil is a sherry colour, pungent taste, and lemon like odour. The chemical composition of the essential oil obtained from leaves of $C$. citratus has been extensively studied using GC and GC/MS methods. It varies according to the geographical origin, geobotanical conditions of the environment, farming practices, plant age, photoperiod, harvest period, genetic differences, and the extraction methods. Despite these differences, such compounds as hydrocarbon terpenes, alcohols, ketones, esters and mainly aldehydes have always been detected (Table 1).

The main component of lemongrass essential oil is citral. It is a mixture of two geometric isomers. The $E$-isomer is known as geranial or citral $\mathrm{A}$ and the $Z$-isomer is known as neral or citral B. Geranial (0.99-48.14\%) dominates over neral $(0-38.32 \%)$ as shown in Tables 1 and 2 . The quality of lemongrass essential oil is generally evaluated by its citral content. According to literature data, lemongrass oil should contain at least $75 \%$ of citral, in order for C. citratus essential oil to be considered as a product of high quality [Barbosa et al., 2008]. Quality and quantity of lemongrass essential oil are highly dependent on the time of plant harvest, because the composition and the content of the essential oil are strictly connected with the developmental stage of the whole plant, plant organs, and cells [Verma et al., 2015]. The harvesting methods usually have little effect on the essential oil yield. The increase in citral content of lemongrass may be influenced by fertilizer application or rhizosphere fungi present in the soil [Shaikh et al., 2019]. The proportion of young leaves to older leaves during harvesting determines the high citral content and subsequently the quality of the essential oil [Tajidin et al., 2012].

Another chemical compound which is often present in the lemongrass essential oil is myrcene. Its percentage content greatly varies and ranges from $0.8 \%$ in the essential oil obtained in Egypt [Mansour et al., 2015] to 25\% in oils obtained in Brazil [Farias et al., 2019] and Nigeria [Kasali et al., 2001]. Such great differences in myrcene content in the essential oil are strictly connected with the geographical region of the world (Table 2).

Besides citral and myrcene, geraniol, citronellal, and limonene are usually detected in amounts higher than $1 \%$ in some samples. The essential oil obtained with HD from Nigerian plants was found to be rich in limonene $(7.90 \%)$, whereas the essential oil obtained with the same method from lemongrass from Kenya was lacking this terpene (Table 1). The amount of citronellal in the essential oil is very diverse: from $0.12 \%$ to $12.77 \%$ (Table 1). As for alcohols identified in the essential oils of $C$. citratus, geraniol was by far the most frequently found one (1.34\% to $21.86 \%$ ). Ester which was identified in significant amounts was geranyl acetate $(0.24 \%$ to $3.42 \%)$. Terpenes which are most frequently detected, besides myrcene and limonene, are $\alpha$-pinene $(0.01-2.12 \%), \beta$-pinene $(0.3-6.00 \%), \beta$-caryophyllene $(0.1-2.46 \%), \beta$-ocimene $(0.15-$ $-0.3 \%)$, and $\alpha$-copaene (1.13-1.29\%). Other minor constituents found in the essential oil are: $\beta$-citronellol, globulol, linalool, hinesol, borneol, isopulegol, trans-verbenol, cis-verbenol, nerol, trans-farnesol, 3-methylcyclohexanol, $\gamma$-eucalyptol, carotol, $\alpha$-cardinol, cubenol, terpinen-4-ol, citronellyl acetate, citronellyl isobutyrate, piperitone, (+)-carvotanacetone, lauraldehyde, 2-undecanone, $\alpha$-cubebene, $\alpha$-muurolene, $\gamma$-muurolene, and $\beta$-guaiene. Table 1 summarises the components found in the essential oil of $C$. citratus obtained with various extraction methods in different regions of the world.

The chemical composition of $C$. citratus essential oil is strictly correlated with the geographical origin. Analysis of the essential oils from C. citratus species from Brazil, Asia, West and Eastern Africa showed high contents of neral and geranial chemotypes (Table 2). In turn, the essential oil from C. citratus of African origin was found to contain a high amount of myrcene, whereas the essential oil from the Ethiopian lemongrass contained geraniol $(40 \%)$ as its main compound, followed by citral (13\%) and $\alpha$-oxobisabolene (12\%) [Ekpenyong et al., 2014]. The major components identified in the Egyptian essential oil were geranial (20.90-40.72\%), 
neral (16.20-34.98\%), geraniol (8.30\%), and linalool $(5.60 \%)$ [Hanaa et al., 2012; Mansour et al., 2015], whereas considerable amounts of geranial (37.80\%) and neral (33.60\%) were found in Saudi Arabia sample [Mansour et al., 2015]. The essential oil obtained from the lemongrass cultivated in Nigeria was poor in citral $(0.99 \%)$, but rich in geraniol $(21.86 \%)$, limonene (7.90\%), and camphene (7.89\%) [Moutassem et al., 2019]. Geranial and neral, limonene, citronellal, myrcene, and geraniol were identified as marker compounds in lemongrass essential oil [Schaneberg \& Khan, 2002]. Marker compounds refer to chemical constituents within a medicinal plant that can be used to verify its potency or identity. As shown in Table 1, limonene, citronellal, and geraniol are not always found. Even geranial and neral are not detected in essential oils obtained from $C$. citratus of different chemotypes [Moutassem et al., 2019].

According to the research conducted by Hanaa et al. [2012], the method of drying has a significant effect on the essential oil content of $C$. citratus. The highest essential oil content $(2.45 \%)$ was determined by these authors in the oil extracted from lemongrass leaves dried in an oven at $45^{\circ} \mathrm{C}$. Whereas, lemongrass leaves dried in sunshine and in shade yielded the oil at percentages of $2.10 \%$ and $2.12 \%$, respectively, without significant difference between them. Geranial $(31.53 \%, 37.24 \%$, and $39.86 \%)$, neral $(30.08 \%, 31.28 \%$, and $34.52 \%)$, and myrcene $(16.61 \%$, $15.42 \%$, and $14.49 \%$ ) were the major components of the essential oils extracted from lemongrass leaves dried by sun, in an oven or in shade, respectively. Generally, drying methods of lemongrass leaves have no tangible effect on the composition of main essential oil components (neral and geranial) [Kumar et al., 2015].

The essential oil composition of lemongrass differs significantly at various harvesting stages [Tajidin et al., 2012]. When lemongrass was harvested 5.5 months after planting, 44 compounds representing $98.64 \%$ of the essential oil were found. In the essential oil obtained from lemongrass harvested 6.5 month after planting, there were only 15 chemical compounds, representing $98.62 \%$ of the essential oil. However, at 7.5 months after planting, 50 chemical compounds were analysed accounting for $97.2 \%$ of the essential oil. Only 13 compounds were always present at each maturity stage, out of which only 7 compounds had concentrations greater than $1 \%$ (neral, geranial, myrcene, 3-undecyne, nerol, geranyl acetate, and juniper camphor). Geranial content in lemongrass oil increased when the lemongrass was harvested at $5.5(37.58 \%)$ to $6.5(45.95 \%)$ months after planting. When the plants were harvested at 7.5 months after planting its content decreased slightly to $42.95 \%$.

\section{BIOLOGICAL ACTIVITY OF LEMONGRASS ESSENTIAL OIL}

Bioactivity of lemongrass has been extensively studied, including especially its antibacterial [Naik et al., 2010; Falcao et al., 2012], antioxidant [Anggraeni et al., 2018], antifungal [Sharma et al., 2017], insecticidal [Brugger et al., 2019], larvicidal [Soonwera et al., 2016], and insect repellent activities [Diabate et al., 2019]. Biological activity of essential oils de- pends on their chemical composition, which can vary dramatically, even within the same species, and also on interactions among their structural components. Even minor essential oil constituents are indispensable and participate in biological functions of the oil due to the synergistic interactions.

\section{Antimicrobial activity}

Antibacterial properties of lemongrass essential oil depend on the presence of three main components: geranial, neral, and myrcene [Onawunmi et al., 1984]. Geranial and neral individually elicit antibacterial action on Gram-negative and Gram-positive organisms, while myrcene, does not show observable antibacterial activity on its own. However, myrcene was observed to generate enhanced bioactivity when it was mixed with either geranial or neral or both. Naik et al. [2010] investigated the effectiveness of lemongrass essential oil against the selected pathogenic bacteria: Staphylococcus aureus, Bacillus subtilis, Bacillus cereus, Escherichia coli, Klebsiella pneumoniae, and Pseudomonas aeruginosa using agar diffusion method and broth dilution method. In general, Gram-positive bacteria were found to be more sensitive to the oil than the Gram-negative ones, which confirmed findings reported earlier by Onawunmi et al. [1984]. P. aeruginosa turned out to be resistant at all the concentrations of lemongrass oil including undiluted solution. S. aureus and B. cereus were more sensitive to lemongrass essential oil and were inhibited at $0.03 \%$ concentration. B. subtilis and E. coli were inhibited by the oil at a concentration of $0.06 \%$, whereas $K$. pneumoniae at $0.25 \%$. Moreover, the tested microorganisms, particularly the Gram-negative bacteria, turned out to be more susceptible to lemongrass oil than standard antibiotics. Similar results were reported by Premathilake et al. [2018] who investigated such pathogenic bacterial strains as E. coli, B. cereus, and S. aureus. Gram-positive bacterial strains were more sensitive to essential oil of $C$ citratus at all of its concentrations than the Gram-negative strain E. coli. Lemongrass essential oil was found to significantly inhibit the growth of such pathogenic foodborne bacteria as Listeria monocytogenes and Salmonella Typhimurium [Reis-Teixeira et al., 2019; Mith et al., 2014]. Food spoilage bacteria (Brochothrix thermosphacta and Pseudomonas fluorescens) were also sensitive to lemongrass essential oil [Mith et al., 2014]. The antibacterial activity of lemongrass essential oil is due to an interaction between the main oil constituents and the bacterial cell membrane. The lipophilic terpenes can modify the fluidity and permeability of the cell membrane or change intracellular $\mathrm{pH}$ and ATP concentrations, which results in cell rupture [Shi et al., 2016]. Nikaido [2003] suggested that the higher resistance of Gram-negative bacteria to essential oils is due to the structure of the outer membrane which protects the bacterial cell against extrinsic chemical agents. The outer membrane is one of the main factors contributing to the resistance of Gram-negative bacteria to hydrophobic antibiotics. However, several studies indicate that lemongrass essential oil can successfully inhibit the growth of numerous multidrug-resistant Gram-negative bacterial strains such as $P$. aeruginosa, E. coli, Enterobacter cloaceae, Morganella morganii, Proteus mirabilis or Burkholderia cepacia [Bučková et al., 2018; Vasireddy et al., 2018]. 
TABLE 1. Composition (\%) of selected Cymbopogon citratus essential oils obtained by different methods or commercially available in different regions of the world.

\begin{tabular}{|c|c|c|c|c|c|c|}
\hline Compound & $\begin{array}{c}\text { Commercial } \\
\text { (South Africa) }^{\mathrm{a}} \\
\end{array}$ & $\begin{array}{l}\text { Hydrodistillation } \\
(\text { China })^{\mathrm{b}}\end{array}$ & $\begin{array}{l}\mathrm{SFE} \mathrm{CO}_{2} \\
{\text { (China })^{\mathrm{b}}}^{\mathrm{S}^{2}}\end{array}$ & $\begin{array}{l}\text { Hydrodistillation } \\
\text { (Nigeria) }^{\mathrm{c}}\end{array}$ & $\begin{array}{l}\text { Commercial } \\
(\text { Greece })^{\mathrm{d}}\end{array}$ & \begin{tabular}{|c|}
$\begin{array}{c}\text { Hydrodistillation } \\
(\text { Kenya })^{\mathrm{e}}\end{array}$ \\
\end{tabular} \\
\hline \multicolumn{7}{|c|}{ Aldehydes and ketones } \\
\hline Camphor & nd & nd & nd & 0.12 & nd & nd \\
\hline 2-Caren-10-al & 0.22 & nd & nd & nd & nd & nd \\
\hline (+)-Carvotanacetone & 0.39 & nd & nd & nd & nd & nd \\
\hline trans-Chrysanthemal & 0.14 & nd & nd & nd & nd & nd \\
\hline Citronellal & 0.34 & 12.77 & 12.57 & 2.37 & 0.6 & 0.12 \\
\hline Geranial & 48.14 & 15.12 & 20.02 & 0.99 & 38.5 & 39.53 \\
\hline Isogeranial & nd & nd & nd & nd & 0.7 & nd \\
\hline Lauraldehyde & nd & 0.30 & 0.13 & nd & nd & nd \\
\hline Neral & 38.32 & 11.15 & 15.11 & nd & 28.7 & 33.31 \\
\hline Piperitone & 0.99 & nd & nd & nd & nd & nd \\
\hline 2-Undecanone & 0.57 & nd & nd & nd & nd & 0.53 \\
\hline Sum & 89.11 & 39.34 & 47.83 & 3.48 & 68.5 & 73.49 \\
\hline \multicolumn{7}{|c|}{ Alcohols } \\
\hline Borneol & nd & nd & 0.76 & 4.72 & nd & nd \\
\hline$\alpha$-Cadinol & nd & 0.25 & 1.47 & 0.37 & nd & nd \\
\hline Carotol & nd & 0.37 & nd & nd & nd & nd \\
\hline$\beta$-Citronellol & 0.09 & nd & nd & 2.83 & 0.1 & 0.34 \\
\hline Cubenol & nd & 0.55 & 3.41 & nd & nd & nd \\
\hline Elemol & nd & nd & nd & 1.37 & 0.1 & \\
\hline$\alpha$-Eudesmol & nd & nd & nd & 0.34 & nd & nd \\
\hline$\beta$-Eudesmol & nd & nd & nd & 0.32 & nd & nd \\
\hline$\gamma$-Eudesmol & & & & 0.24 & & \\
\hline$\gamma$-Eucalyptol & nd & nd & 0.80 & nd & 0.6 & nd \\
\hline trans-Farnesol & nd & nd & 1.34 & nd & nd & nd \\
\hline Geraniol & 1.34 & 9.39 & 6.43 & 21.86 & 4.4 & 3.05 \\
\hline Globulol & nd & 1.37 & 0.55 & nd & nd & nd \\
\hline Hinesol & nd & 0.91 & 2.80 & nd & nd & nd \\
\hline Isoborneol & nd & nd & nd & nd & 0.2 & nd \\
\hline Isopulegol & nd & 0.35 & 0.18 & nd & nd & nd \\
\hline Linalool & 0.98 & nd & nd & 0.70 & 1.6 & 1.29 \\
\hline 3-Methylcyclohexanol & nd & 0.71 & 2.01 & nd & nd & nd \\
\hline E-Methyleugenol & nd & nd & nd & 0.19 & nd & nd \\
\hline Methylisoeugenol & nd & nd & nd & 7.50 & nd & nd \\
\hline Nerol & nd & 0.35 & 0.19 & nd & 0.1 & 0.34 \\
\hline Terpinen-4-ol & nd & nd & nd & 2.21 & 0.1 & nd \\
\hline cis-Verbenol & nd & 0.46 & 0.95 & nd & nd & nd \\
\hline trans-Verbenol & nd & nd & 0.33 & nd & nd & nd \\
\hline Sum & 2.41 & 14.71 & 21.22 & 42.65 & 7.2 & 5.02 \\
\hline
\end{tabular}




\begin{tabular}{|c|c|c|c|c|c|c|}
\hline Compound & $\begin{array}{c}\text { Commercial } \\
\text { (South Africa) }^{\mathrm{a}}\end{array}$ & $\begin{array}{c}\text { Hydrodistillation } \\
\text { (China) }^{\mathrm{b}}\end{array}$ & $\begin{array}{l}\mathrm{SFE} \mathrm{CO}_{2} \\
\text { (China) }^{\mathrm{b}}\end{array}$ & $\begin{array}{c}\text { Hydrodistillation } \\
\text { (Nigeria)c }^{c}\end{array}$ & 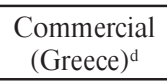 & $\begin{array}{c}\text { Hydrodistillation } \\
\text { (Kenya) }^{\text {e }}\end{array}$ \\
\hline \multicolumn{7}{|c|}{ Esters } \\
\hline Bornyl acetate & nd & nd & nd & 0.71 & nd & nd \\
\hline Citronellyl acetate & nd & nd & 0.23 & 0.98 & 4.3 & nd \\
\hline Citronellyl isobutyrate & nd & 0.61 & 1.27 & nd & nd & nd \\
\hline Geranyl acetate & 0.82 & 2.24 & 0.65 & 3.42 & nd & 0.24 \\
\hline Geranyl butyrate & nd & nd & nd & nd & 0.2 & nd \\
\hline Geranyl formate & 0.17 & nd & nd & nd & 0.2 & nd \\
\hline Terpenyl acetate & nd & nd & nd & 0.29 & nd & nd \\
\hline Sum & 0.99 & 2.85 & 2.15 & 5.40 & 4.7 & 0.24 \\
\hline \multicolumn{7}{|c|}{ Hydrocarbon terpenes } \\
\hline Bicyclogermacrene & nd & nd & nd & 2.60 & nd & nd \\
\hline$\beta$-Bourbonene & nd & 1.97 & nd & nd & nd & nd \\
\hline$\delta$-Cadinene & nd & nd & nd & 4.10 & 1.0 & nd \\
\hline Camphene & nd & nd & nd & 7.89 & 1.0 & nd \\
\hline 3-Carene & nd & 0.46 & nd & nd & nd & nd \\
\hline$\beta$-Caryophyllene & 0.17 & 2.46 & 0.10 & 1.86 & 1.4 & 0.15 \\
\hline$\alpha$-Copaene & nd & 1.29 & 1.13 & nd & nd & nd \\
\hline$\alpha$-Cubebene & nd & 0.94 & 0.46 & nd & nd & nd \\
\hline p-Cymene & nd & nd & nd & 0.19 & nd & nd \\
\hline$\beta$-Elemene & nd & nd & nd & 1.07 & 0.1 & nd \\
\hline Germacrene D & nd & nd & nd & 0.97 & 0.1 & nd \\
\hline$\alpha$-Guaiene & nd & 0.25 & 0.45 & nd & nd & nd \\
\hline$\beta$-Guaiene & nd & 0.14 & nd & nd & nd & nd \\
\hline$\alpha$-Humulene & nd & nd & nd & 0.30 & nd & nd \\
\hline D-Limonene & 0.18 & 0.20 & 3.55 & 7.90 & 6.9 & nd \\
\hline 8-Methyl-1-hendecene & nd & nd & 0.18 & nd & nd & nd \\
\hline$\alpha$-Muurolene & nd & 0.26 & 0.30 & 4.10 & nd & nd \\
\hline$\gamma$-Muurolene & nd & 1.67 & 0.20 & 0.17 & nd & nd \\
\hline Myrcene & nd & nd & nd & 0.60 & 0.3 & 11.41 \\
\hline$\beta$-Ocimene & 0.25 & nd & 0.15 & nd & 0.3 & nd \\
\hline Perillene & 0.19 & nd & nd & nd & nd & nd \\
\hline$\beta$-Phellandrene & nd & nd & nd & 0.32 & nd & nd \\
\hline$\alpha$-Pinene & nd & 0.71 & 0.67 & 2.12 & 0.6 & 0.01 \\
\hline$\beta$-Pinene & nd & 4.31 & 6.00 & nd & 0.3 & nd \\
\hline Sabinene & nd & nd & nd & 0.14 & 0.4 & nd \\
\hline Terpinolene & nd & nd & nd & 0.50 & 0.1 & nd \\
\hline $\begin{array}{l}(6 E, 10 E)-2,6, \\
\text { 12,15-Tetramethylhexadeca- } \\
-2,6,10,14 \text {-tetraen-8-yne }\end{array}$ & 0.44 & nd & nd & nd & nd & nd \\
\hline 1-Undecyne & 0.51 & nd & nd & nd & nd & nd \\
\hline Sum & 1.74 & 14.66 & 13.19 & 34.83 & 12.5 & 11.57 \\
\hline
\end{tabular}

nd - not detected; SFE $\mathrm{CO}_{2}$ - supercritical fluid extraction with $\mathrm{CO}_{2}$; ${ }^{\mathrm{a} M b i l i}$ et al. [2017]; ${ }^{\mathrm{b} W u}$ et al. [2019]; ${ }^{\circ}$ Moutassem et al. [2019]; ${ }^{\mathrm{d} H a d j i l o u k a ~ e t ~ a l . ~}$ [2017]; ${ }^{\mathrm{C}}$ Matasyoh et al. [2011]. 
TABLE 2. Major component contents of Cymbopogon citratus essential oil (\%) obtained from plants harvested in different regions of the world.

\begin{tabular}{|c|c|c|c|c|}
\hline \multirow{2}{*}{ Country/ region } & \multicolumn{3}{|c|}{ Compound } & \multirow{2}{*}{ References } \\
\hline & Geranial & Neral & Myrcene & \\
\hline Algeria & 42.16 & 31.52 & 7.45 & Boukhatem et al. [2014a] \\
\hline Benin & 39.5 & 35.5 & nd & Kpoviessi et al. [2014] \\
\hline \multirow{2}{*}{ Brazil } & 39.9 & 30.1 & 1.59 & Andrade et al. [2009] \\
\hline & 31.89 & 24.62 & 25.37 & Farias et al. [2019] \\
\hline Burkina Faso & 48.1 & 34.6 & 11.0 & Bassolé et al. [2011] \\
\hline Cameroon & 37.7 & 21.2 & 2.5 & Nguefack et al. [2012] \\
\hline \multirow{2}{*}{ Egypt } & 40.72 & 34.98 & 15.69 & Hanaa et al. [2012] \\
\hline & 20.9 & 16.2 & 0.8 & Mansour et al. [2015] \\
\hline Iran & 39.16 & 30.95 & 3.57 & Amini et al. [2016] \\
\hline Ivory Coast & 45.3 & 32.5 & 18.1 & Sidibé et al. [2001] \\
\hline Malaysia & $37.58-45.95$ & $29.44-31.13$ & $3.18-7.68$ & Tajidin et al. [2012] \\
\hline Mali & 30.5 & 26.3 & 18.1 & Sidibé et al. [2001] \\
\hline Nigeria & 33.7 & 26.5 & 25.3 & Kasali et al. [2001] \\
\hline Saudi Arabia & 37.8 & 33.6 & 8.4 & Mansour et al. [2015] \\
\hline Sri Lanka & 35.97 & 26.5 & nd & Premathilake et al. [2018] \\
\hline Zambia & 39.0 & 29.4 & 18.0 & Chisowa et al. [1998] \\
\hline
\end{tabular}

nd - not detected.

The antimicrobial activity of lemongrass essential oil is usually higher against fungi than bacteria. Premathilake et al. [2018] found that lemongrass essential oil exhibited fungitoxic activity against Colletotricum truncatum, Fusarium spp., Penicillium spp., and Crysosporium spp. All four different concentrations of the essential oil used in this experiment elicited 100\% inhibition of Fusarium spp., Penicillium spp., and Crysosporium spp. C. truncatum was also inhibited by the lemongrass essential oil but higher concentrations of the oil were necessary. The essential oil of $C$. citratus was also investigated towards Candida albicans, Candida parapsilosis, Candida tropicalis, Candida glabrata, and Candida krusei [da Silva et al., 2008]. All those strains proved to be sensitive to $C$. citratus essential oil, which indicates new perspectives in the potential application of lemongrass oil in typical Candida infections. Tzortzakis \& Economakis [2007] reported a broad antifungal activity of essential oil of $C$. citratus against such food pathogens as Aspergillus niger, Colletotrichum coccodes, Botrytis cinerea, Cladosporium herbarum, and Rhizopus stolonifer. Amini et al. [2016] demonstrated that lemongrass oil effectively controlled mycelium growth of three Phytophthora species: P. capsici, P. drechsleri, and P. melonis. The Phytophora genus is a plant-damaging mold which causes enormous economic losses in crops as well as environmental destruction in natural ecosystems. Helal et al. [2006] investigated the antifungal activity of essential oil of C. citratus against Aspergillus niger ML2-strain. Lemongrass oil produces a fungi toxic effect against postharvest patho- gens of the Aspergillus genus: A. flavus, A. parasiticus, and A. clavatus [Matasyoh et al., 2011; Bozik et al., 2017]. Five mycotoxigenic species isolated from maize samples, including A. flavus, A. parasiticus, A. ochraceus, A. niger, and A. fumigatus, were also found to be sensitive to lemongrass essential oil [Matasyoh et al., 2011]. The highest activity of the oil was observed against $A$. niger with the minimum inhibitory concentration of $15 \mathrm{mg} / \mathrm{mL}$ and the highest resistance was observed from A. flavus with an MIC of $118 \mathrm{mg} / \mathrm{mL}$. Sharma et al., [2017] recorded an inhibitory effect of lemongrass essential oil against a pathogenic strain of Fusarium oxysporum. The genus Fusarium is infamous for infecting plants, leading to economic losses in agriculture and is known to produce mycotoxins in cereal crops. Lemongrass essential oil showed complete inhibition of spore germination at a concentration of $250 \mathrm{ppm}, \mathrm{IC}_{50}$ value was found to be $0.98 \mathrm{ppm}$.

According to Boukhatem et al. [2014b], lemongrass oil showed a potent antimicrobial activity against Gram-positive bacteria and exhibited the strongest antifungal effect against Candida albicans and C. parapsilosis. MIC varied from 0.019 to $1.25 \mathrm{mg} / \mathrm{mL}$ for Gram-positive bacteria and yeasts, indicating $S$. aureus, S. epidermidis, and $C$. albicans as the most susceptible strains. Moreover, the diameter of inhibition zone (DIZ) increased with an increasing essential oil concentration. Considerably superior antimicrobial activity was observed in the vapour phase. The DIZ resulting from the exposure to essential oil vapour was significantly larger than that from the same volume in the liquid phase. The DIZ 
varied from 22 to $90 \mathrm{~mm}$ for Candida strains. Essential oil in the vapour phase may be an effective antimicrobial system and has advantages over the oil in the liquid phase. These results [ Boukhatem et al., 2014b] imply that lemongrass oil could be useful for the development of novel types of natural preservatives for food control.

The high antifungal activity of lemongrass essential oil is attributed to the presence of two isomers of citral [Leite et al., 2014]. According to Harris [2002], citral seems to interact mostly with the cell wall of fungi. Such interaction affects its construction, inhibiting its synthesis, which results in cell death. Earlier literature suggested that the fungitoxic activity of citral stems from its capability to form a charge transfer complex with fungal cell tryptophan, leading to fungi death [Kurita et al., 1981]. In recent studies, the antifungal activity of citral was evaluated against Geotrichum citri-aurantii [Zhou et al., 2014]. The experiment revealed that citral significantly inhibited mycelial growth. Antifungal properties of citral were attributed to cell membrane destruction and to the subsequent leakage of cellular constituents. The inhibiting activity of lemongrass essential oil may also stem from the synergistic effect of individual minor or major compounds [Nguefack et al., 2012]. Further studies are needed to completely describe its effects especially if it is going to be used in the future as a component of new antifungals. The other major component of lemongrass essential oil - myrcene is not known to exhibit any antifungal activity. Components with hydroxyl moiety have been known to be active but with differing specificity and levels of activity, which is related not only to the functional group present but also to hydrogen bonding parameters [Skaltsa et al., 2003]. The mechanism of action of geraniol, one of the main alcohols found in lemongrass essential oil, probably does not involve complexation with ergosterol or inhibiting the fungal cell wall synthesis [Leite et al., 2015]. Whereas, Pereira et al. [2015] suggested that the antifungal activity of geraniol and citronellol, i.e. two monoterpene alcohols, against Trichophyton rubrum involves ergosterol biosynthesis inhibition. In general, high lipophilic nature and low molecular weight of terpenes/terpenoids, that are irreplaceable constituents of lemongrass oil, determine its high antifungal activity which probably involves disrupting the cell membrane, causing cell death or inhibiting the sporulation and germination of fungi. Therefore, many in vitro tests have proved terpenes/terpenoids to show much lower antimicrobial activity when used as singular compounds compared to the whole essential oil [Lu et al., 2013].

\section{Antioxidant activity}

The antioxidant activity of $C$. citratus essential oil is due to the synergistic effect of all its constituents [Guimarães et al., 2011]. However, recent reports indicate that the main terpenoid component of the essential oil - citral - shows antioxidant activity as well, which is a result of co-oxidation with the target substrate and cross-termination of the oxidative chain [Baschieri et al., 2017]. The antioxidant properties of lemongrass essential oil have been studied by many researchers, though there are some discrepancies between the results, probably due to the different geographical origin of the plant, different extraction methods, and methodology used to evaluate its antioxidant activity. The antioxidant activity assessment requires a combination of various methods because there are significant differences in sample preparation (solvent, temperature etc.), selection of end-points, and even the expression of results, hence the comparison between values reported by different scientists may be problematic. A single method will provide only a primary knowledge about antioxidant properties, whereas a combination of methods will produce more detailed information about the antioxidant properties of the sample.

Lawrence et al. [2015] thoroughly checked the antioxidant activity of lemongrass leaves oil from India using four different methods: free radical scavenging activity (DPPH method), reducing power assay, nitric oxide scavenging method, and $\beta$-carotene bleaching assay. Inhibition constant $\mathrm{IC}_{50}$ values recorded for DPPH and NO scavenging method were $0.5 \mathrm{mg} / \mathrm{mL}$ and $2.0 \mathrm{mg} / \mathrm{mL}$, respectively. The reducing activity was also significant. The results proved that lemongrass essential oil is effective in scavenging free radical and has the potential to be a powerful antioxidant. Another study was done by Mansour et al. [2015] in which higher antioxidant activity was demonstrated for Egyptian lemongrass essential oil with $\mathrm{IC}_{50} 1.0 \mathrm{mg} / \mathrm{mL}$ in comparison to the Saudi Arabian lemongrass volatile oil with $\mathrm{IC}_{50} 6.9 \mathrm{mg} / \mathrm{mL}$. The strong $\mathrm{DPPH}^{*}$ scavenging ability of the Egyptian oil was attributed to its unsaturated alcohols and phenolic compounds such as linalool $(5.6 \%)$, geraniol $(8.3 \%)$, terpin-4-ol $(2.1 \%)$, and eugenol (0.4\%). On the other hand, Anggraeni et al. [2018] reported a low antioxidant activity of the Indonesian lemongrass essential oil when compared to ascorbic acid and commercial lemongrass oil used as a reference material. Similarly, Viuda-Martos et al. [2010] reported a low radical-scavenging capacity of lemongrass oil using a stable DPPH radical with $\mathrm{IC}_{50} 199.63 \mathrm{mg} / \mathrm{mL}$, whereas the ferric reducing antioxidant capacity (FRAC) of the essential oil was high. The same research group found lemongrass essential oil to be highly effective in chelating iron(II) ions, better than ascorbic acid and BHT. Viuda-Martos et al. [2010] also demonstrated that lemongrass EO might show a pro-oxidant activity, which was determined with the Rancimat method.

Various other scientists have also worked on the antioxidant activity of $C$. citratus essential oil. Guimarães et al. [2011] reported a low antioxidant activity of Brazilian lemongrass essential oil using the methodology that measures the scavenging of a stable DPPH radical; however, when analysed using the methodology that employs the $\beta$-carotene/linoleic acid emulsion system, the oil showed significant antioxidant activities. Using the Folin-Ciocalteau method, Mirghani et al. [2012] demonstrated the highest phenolics content in the essential oil extracted from lemongrass stalk, i.e. $2100.8 \mathrm{mg}$ GAE/L. The high antioxidant activity of lemongrass stalk oil was also confirmed with the DPPH scavenging assay. The results obtained by Hartartie et al. [2019] indicate that the antioxidant activity of lemongrass essential oil depends on the method of distillation and on the part of the plant used. The antioxidant activity measured with DPPH free radical scavenging assay showed that steam-distilled lemongrass stalk oil had the highest antioxidant activity (72.724\%), while water-distillated oil from the whole plant of lemongrass had 
a lower antioxidant activity reaching up to $70.113 \%$. The antioxidant activity of an essential oil made of leaves using the steam distillation method was higher $(60.808 \%)$ than that obtained by water distillation $(57.331 \%)$.

The antioxidant properties of lemongrass essential oils are attributed to the presence of terpenoid and phenolic compounds which may demonstrate their redox properties employing different possible mechanisms, like: hydrogen donation, free radical scavenging activity, transition metal chelating activity, and/or singlet oxygen quenching capacity [Viuda-Martos et al., 2010]. In literature, the antioxidant properties of lemongrass essential oil are attributed to the mixture of different chemical compounds of the oil, because even minor constituents may influence and modulate the activity of the whole oil.

The antioxidant properties of $C$. citratus essential oil might be worth of consideration in terms of essential oil incorporation into formulations of nutraceuticals or/and functional food. Antioxidants can scavenge free radicals and retard lipid oxidation in food products, which is the main cause of food quality deterioration.

\section{Anti-inflammatory properties}

Traditionally, lemongrass is also known for analgesic and anti-inflammatory properties, however only few studies have been carried out to substantiate these effects of lemongrass oil. Only recently, a few research groups have undertaken studies to investigate anti-inflammatory properties of lemongrass essential oil and its major constituent - citral. Boukhatem et al. [2014a] used carrageenan-induced mouse paw oedema to determine the anti-inflammatory effect of Algerian lemongrass oil. The experiment has proved that lemongrass essential oil is able to considerably inhibit inflammation processes. The degree of oedema inhibition after 90 min of the oral intake turned out to be $82.75 \%$ for the dose of $10 \mathrm{mg} / \mathrm{kg}$, while only a little higher degree of oedema inhibition $(86.2 \%)$ was observed for a higher oil dose $(100 \mathrm{mg} / \mathrm{kg})$. The anti-inflammatory activity of the lemongrass oil was compared with the standard drug diclofenac which showed similar oedema inhibition (86.2\%) to the lemongrass oil when used in a dose of $50 \mathrm{mg} / \mathrm{kg}$. The detailed mechanism of the anti-inflammatory effect of the lemongrass essential oil remains unexplained. However, it has been indicated that several components of lemongrass oil may cause partial inhibition of the release of inflammation mediator molecules. The main plant constituents, particularly aldehyde monoterpenes (geranial and neral), have already been reported to be able to control inflammatory processes [Perez et al., 2011].

\section{LEMONGRASS ESSENTIAL OIL USES FOR FOOD PRESERVATION}

Essential oils are considered as natural substituents of chemical preservatives, since their use in food is regarded as safe and natural. Food products containing essential oils are accepted by consumers and also meet the demands for "green" processing. However, the practical application of essential oils is limited due to their characteristic flavour, possible interactions with food components and structure, which results in reduction of their efficacy [Amany et al., 2010]. Among the various essential oils, the oil of $C$. citratus has been recognised most promising for uses as a food preservative since it exhibits a variety of fundamental and novel bioactivities. Owing to their GRAS status, essential oils are not harmful and are more widely accepted by consumers than the "synthetic" agents.

Currently, the focus of several research laboratories is to investigate the application of lemongrass oil especially in meat preservation. In the meat industry, a number of chemical additives have already been used, but the consumers' growing concern about the safety of food products has contributed to the shift of the interests from synthetic compounds to natural ones. The antimicrobial and antioxidant activity of lemongrass oil can restrain foodborne pathogens and spoilage organisms against their development and subsequent deterioration of meat products. The advantages of such a treatment of meat are that lemongrass essential oil may be useful in extending shelf-life of meat products, preserving meat quality, preventing economic loss, and providing the consumer with meat products containing more acceptable natural additives.

Amany et al. [2010] studied the antioxidant and antimicrobial effectiveness of lemongrass oil at various concentrations on the quality of refrigerated fresh minced beef $\left(4^{\circ} \mathrm{C}\right)$. The results were compared with the bioactivity of garlic oil and thyme oil, which are widely renowned for their antimicrobial properties against spoilage flora in meat products. Lemongrass oil at a concentration of $1.5 \%$ showed a significant effectiveness in decreasing aerobic plate count, coliform count, Enteriobacteriaceae count, and Staphylococci count. The antimicrobial activity of garlic and thyme oils was not as strong as that of the lemongrass oil. The decreased content of total volatile nitrogen, which determines the degree of meat deterioration during storage, indicated that all oils successfully inhibited the spoilage of minced meat at a comparable level. In the same experiment, lemongrass oil was found to be the most effective in preventing auto-oxidation of meat lipids and bacteriological and/or oxidative rancidity, which was estimated by the evaluation of decrease in thiobarbituric acid values. Different degradation reactions, involving lipid oxidation, influence the sensory profile of meat products. All tested oils proved to enhance the sensory properties of all the refrigerated beef samples to the similar extent. The greatest enhancement was observed for the samples containing $1.5 \%$ of lemongrass oil. In general, the best results in refrigerated minced beef preservation were demonstrated by lemongrass oil.

In a recent study, Zaki et al. [2018] evaluated the effect of using lemongrass essential oil in the formulation of camel burgers on changes in their physical, chemical, microbiological, and sensory properties during cold storage $\left(4^{\circ} \mathrm{C}\right)$. Physical properties (percentage of cooking loss, percentage of reduction in diameter) were improved for camel burgers containing $1 \%$ of lemongrass oil. The total volatile nitrogen and thiobarbituric acid values significantly decreased for samples with lemongrass oil when compared to the control ones. The burgers formulated with addition of $1 \%$ of lemongrass oil were found to show the lowest total bacterial count, and were given the highest scores for taste, aroma, colour, 
texture, and acceptability in the sensory analysis. Lemongrass essential oil antimicrobial properties may support storage stability of meat when combined with other essential oil. The combination of lemongrass and ginger essential oil successfully extended the shelf life of chicken meat [Hartanti et al., 2018].

The antimicrobial potential of lemongrass essential oil was also tested in reducing the microbial population of cream-filled baked goods [Vazirian et al., 2012]. Five main food-borne pathogens including: Bacillus cereus, Candida albicans, Escherichia coli, Salmonella typhimurium, and Staphylococcus aureus, were added manually to cream-filled cakes together with $1 \mu \mathrm{L} / \mathrm{mL}$ of the lemongrass essential oil. After $72 \mathrm{~h}$ of storage, no observable microflora was detected in the baked cakes, except for $S$. aureus in the case of which lemongrass essential oil proved ineffective.

The antimicrobial effectiveness of lemongrass oil against Salmonella enterica serovar Newport on organic leafy vegetables such as romaine and iceberg lettuce as well as mature and baby spinach was investigated by Moore-Neibel et al. [2012]. Samples of leaves inoculated with Salmonella Neport were dipped in a lemongrass oil solution for 1 to $2 \mathrm{~min}$ and then stored for 1 to 3 days. Significant inhibition of $S$. Neport growth on fresh leafy greens was observed. The antibacterial activity of lemongrass oil depended on oil concentration and storage time. The highest reduction was observed (according to the activity order) on baby spinach, mature spinach, and romaine lettuce. The differences in the effectiveness of lemongrass oil among species of leafy green vegetables may be attributed to the surface morphology, chemical composition, and nutrient content of leaves. However, little differences were reported for the samples stored under refrigeration and abuse temperatures.

At present, research laboratories have focused on investigating the antimicrobial activity of lemongrass essential oil in the vapour phase. Such analyses were undertaken by, e.g., Mani-López et al. [2018] who evaluated the fungicidal properties of lemongrass oil vapours on the growth of Penicillium expansum inoculated on bread. The growth of $P$. expansum was inhibited for 21 days at $20^{\circ} \mathrm{C}$ with $750 \mu \mathrm{L}$ of oil $/ \mathrm{L}$ air. The increasing concentration of the oil resulted in greater inhibition. No significant differences were observed in the sensory analysis for the samples exposed and not exposed to lemongrass oil vapours. Lemongrass essential oil vapours were also reported to control anthracnose disease development on papaya without affecting its natural ripening process [Ali et al., 2015]. A number of studies have demonstrated that the antifungal and antimicrobial activities of essential oils in the vapour phase are more effective than in the liquid phase. These have been extensively reviewed by Reyes-Jurado et al. [2019].

Lemongrass oil may also play a vital role in the inhibition of several fundamental postharvest pathogens like Botrytis cinerea, Colletotrichum coccodes, Cladosporium herbarum, and Rhizopus stolonifer that are important for food preservation [Mbili et al., 2017; Tzortzakis \& Economaki, 2007]. Lemongrass essential oil as well as powdered plant have been recorded to prevent storage deterioration and aflatoxin contamination of melon seeds infected by Aspergillus flavus, A. ni- ger, A. tamarii, and Penicilium citrinum [Bankole et al., 2005]. The chemical composition of melon seeds was not affected by lemongrass essential oil and the effects were nearly similar to a commercial fungicide iprodione.

The antifungal activity of essential oil of $C$. citratus grown in Iran was investigated for controlling three species of Phytophthora, including P. capsici, P. drechsleri, and P. melonis, on pepper, cucumber, and melon under in vitro and greenhouse conditions, respectively [Amini et al., 2016]. Essential oil of $C$. citratus inhibited in vitro the growth of $P$. capsici $(91.9 \%)$, P. drechsleri (91.2\%), and P. melonis (94.6\%) and under greenhouse conditions the growth of $P$. capsici $(60.5 \%)$, P. drechsleri (47.4\%), and P. melonis (55.3\%), which affords new perspectives for its application as an alternative to synthetic compounds for integrated control of diseases caused by Phytophthora species in crop, vegetable, and ornamental plants after suitable clinical trials.

It was also reported that lemongrass oil increases the shelf life of different fruits like guava [Murmu \& Mishra, 2018], strawberries [Kahramanoglu, 2019], table grapes [Sonker et al., 2014], apples [Frankova et al., 2016; Jo et al., 2014] as well as fruit juice [Tyagi et al., 2014]. It was also found effective in preserving processed foods like cheese [Cui et al., 2016]. A recent report has indicated that lemongrass essential oil may influence lactic cultures in dairy products [Farias et al., 2019], which may curb its applicability in this sector of food industry. The application of $C$. citratus essential oil in food preservation was comprehensively reviewed by Ekpenyong \& Akpan [2017].

Although numerous studies have indicated that lemongrass essential oil may serve as a potential food preservative, little is known about its toxic effects. Some reports suggest that its high levels in food products may have an adverse impact on the gustatory and olfactory systems [Smith et al., 2005]. On the other hand, lemongrass essential oil used in small concentrations is considered safe for human consumption [Sinha et al., 2014]. In vitro studies have shown that the antimicrobial activity of lemongrass essential oil is predominantly between 0.2 and $10 \mu \mathrm{l} / \mathrm{mL}$. In food products the concentration of the essential oil is much higher $(25-100$-fold $)$ in order to achieve the comparable antimicrobial activity. The ADI value recommended by the European Union for geraniol is $0.5 \mathrm{mg} / \mathrm{kg}$ body weight/ day, hence food products contain excessive doses of the essential oil [Commission Implementing Regulation (EU) No 570/2013]. In many countries, the application of essential oils is not regulated whatsoever. Moreover, inappropriate and random uses of the lemongrass essential oil may result in health problems triggered by genetic damages, carcinogenic effects, and mutations [Sousa et al., 2010]. Thus, further studies on the toxicity of lemongrass essential oil and the comprehensive safety evaluation are needed.

\section{CONCLUSION}

There is a growing interest in the application of the essential oil of $C$. citratus in the food system. The oil contains many phytoconstituents such as terpenes, terpenoids, esters, and phenolic compounds, which are responsible for different biological activities, primarily antibacterial and antifungal 
ones. Many studies have confirmed that lemongrass essential oil may serve as a natural meat preservative offering protection against various microorganisms, increasing shelf-life of the product, and ensuring its quality. Before industrial application in the meat industry, further research is necessary to explore the efficiency of suitable concentrations of the oil. Additionally, the use of lemongrass oil opens new perspectives to the management of storage fungi, which not only deteriorate the quality of food but also may cause food-borne diseases. In general, lemongrass essential oil is a promising plant product for preserving stored foodstuffs replacing synthetic additives which are associated with various adverse human health effects. Its application in stored food products may be a good solution in remote rural areas which still have no possibility to use modern storage system.

\section{CONFLICT OF INTERESTS}

The authors declare they do not have any conflicts of interest.

\section{REFERENCES}

1. 21 CFR § 182.20, 2018.

2. 21 CFR § 184.1240, 2019.

3. Ajayi, E.O., Sadimenko, A.P., Afolayan, A.J. (2016). GC-MS evaluation of Cymbopogon citratus (DC) Stapf oil obtained using modified hydrodistillation and microwave extraction methods. Food Chemistry, 209, 262-266.

4. Alhassan, M., Lawal, A., Nasiru, Y., Suleiman, M., Safiya, A.M., Bello, N. (2018). Extraction and formulation of perfume from locally available lemon grass leaves. ChemSearch Journal, 9(2), 40-44.

5. Ali, A., Pheng, T.W., Mustafa, M.A. (2015). Application of lemongrass oil in vapour phase for the effective control of anthracnose of "Sekaki' papaya. Journal of Applied Microbiology, 118(6), 1456-1464.

6. Al-Marzouqi, A.H., Rao, M.V., Jobe, B. (2007). Comparative evaluation of SFE and steam distillation methods on the yield and composition of essential oil extracted from spearmint (Mentha spicata). Journal of Liquid Chromatography \& Related Technologies, 30(4), 463-475.

7. Amany, M.S., Reham, A.A., Gehan, S.A.A. (2010). Studies on antimicrobial and antioxidant efficiency of some essential oils in minced beef. Journal of American Science, 6(12), 691-700.

8. Amini, J., Farhang, V., Javadi, T., Nazemi, J. (2016). Antifungal effect of plant essential oils on controlling Phytophthora species. Plant Pathology Journal, 32(1), 16-24.

9. Andrade, E.H., Zoghbi, M.D., Lima, M.D. (2009). Chemical composition of the essential oils of Cymbopogon citratus (DC) Stapf cultivated in North of Brazil. Journal of Essential Oil Bearing Plants, 12(1), 41-45.

10. Anggraeni, N.I., Hidayat, I.W., Rachman, S.D., Ersanda. (2018). Bioactivity of essential oil from lemongrass (Cymbopogon citratus Stapf) as antioxidant agent. 1st International Conference and Exhibition on Powder Technology Indonesia (ICePTi) 2017, AIP Conference Proceedings, 1927, art. no. UNSP039997.

11. Avoseh, O., Oyedeji, O., Rungqu, P., Nkeh-Chungag, B., Oyedeji, A. (2015). Cymbopogon species; ethnopharmacology, phyto- chemistry and the pharmacological importance. Molecules, 20(5), 7438-7453.

12. Bankole, S.A., Joda, A.O, Ashidi, J.S. (2005). The use of powder and essential oil of Cymbopogon citratus against mould deterioration and aflatoxin contamination of 'egusi" melon seeds. Journal of Basic Microbiology, 45(1), 20-30.

13. Barbosa, L.C.A., Pereira, U.A., Martinazzo, A.P., Maltha, C.R.A., Teixeira, R.R., Melo, E.D. (2008). Evaluation of the chemical composition of Brazilian commercial Cymbopogon citratus (D.C) Stapf Samples. Molecules, 13(8), 1864-1874.

14. Baschieri, A., Ajvazi, M.D., Tonfack, J.L.F., Valgimigli, L., Amorati, R. (2017). Explaining the antioxidant activity of some common non-phenolic components of essential oils. Food Chemistry, 232, 656-663.

15. Bassolé, I.H.N., Lamien-Meda, A., Bayala, B., Obame, L.C., Ilboudo, A.J., Franz, C., Novak, J., Nebié, R.C., Dicko, M.H. (2011). Chemical composition and antimicrobial activity of Cymbopogon citratus and Cymbopogon giganteus essential oils alone and in combination. Phytomedicine, 18(12), 1070-1074.

16. Berk, Z. (2013). Distillation. Chapter 13. In Z. Berk (Ed.) Food Process Engineering and Technology. $2^{\text {nd }}$ Edition, Elsevier Inc., pp. 329-352.

17. Boukhatem, M.N., Ferhat, M.A., Kameli, A., Saidi, F., Kebir, H.T. (2014a). Lemon grass (Cymbopogon citratus) essential oil as a potent anti-inflammatory and antifungal drugs. Libyan Journal of Medicine, 9, art. no. 25431.

18. Boukhatem, M.N., Kameli, A., Ferhat, M.A., Tayebi, K., Saidi, F. (2014b). The food preservative potential of essential oils: Is lemongrass the answer? Journal of Consumer Protection and Food Safety, 9(1), 13-21.

19. Bozik, M., Cisarova, M., Tancinova, D., Kourimska, L., Hleba, L., Kloucek, P. (2017). Selected essential oil vapours inhibit growth of Aspergillus spp. in oats with improved consumer acceptability. Industrial Crops and Products, 98, 146-152.

20. Brugger, B.P., Martinez, L.C., Plata-Rueda, A., Castro, B.M.D.E., Soares, M.A., Wilcken, C.F., Carvalho, A.G., Serrao, J.E., Zanuncio, J.C. (2019). Bioactivity of the Cymbopogon citratus (Poaceae) essential oil and its terpenoid constituents on the predatory bug, Podisus nigrispinus (Heteroptera: Pentatomidae). Scientific Reports, 9, art. no. 8358.

21. Bučková, M., Puškárová, A., Kalászová, V., Kisová, Z., Pangallo, D. (2018). Essential oils against multidrug resistant gram-negative bacteria. Biologia, 73(8), 803-808.

22. Carbajal, D., Casaco, A., Arruzazabala, L., Gonzalez, R., Tolon, Z. (1989). Pharmacological study of Cymbopogon citratus leaves. Journal of Ethnopharmacology, 25(1), 103-107.

23. Carlson, L.H.C., Machado, R.A.F., Spricigo, C.B., Pereira, L.K., Bolzan, A. (2001). Extraction of lemongrass essential oil with dense carbon dioxide. Journal of Supercritical Fluids, 21 (1), 33-39.

24. Chisowa, E.H., Hall, D.R., Farman, D.I. (1998). Volatile constituents of the essential oil of Cymbopogon citratus Stapf grown in Zamibia. Flavour and Fragrance Journal, 13(1), 29-30.

25. Commission Implementing Regulation (EU) No $570 / 2013$ of 17 June 2013 approving the active substance geraniol, in accordance with Regulation (EC) No 1107/2009 of the European Parliament and of the Council concerning the placing of plant protection products on the market, and amending the Annex to Implementing Regulation (EU) No 540/2011 Text with EEA relevance. 
26. Cui, H.Y., Wu, J., Lin, L. (2016) Inhibitory effect of liposomeentrapped lemongrass oil on the growth of Listeria monocytogenes in cheese. Journal of Dairy Science, 99(8), 6097-6104.

27. da Silva, C.D., Guterres, S.S., Weisheimer, V., Schapoval, E.E.S. (2008). Antifungal activity of the lemongrass oil and citral against Candida spp. Brazilian Journal of Infectious Diseases, 12(1), 63-66.

28. d'Avila, J.V., Martinazzo, A.P., dos Santos, F.S., Teodoro, C.E.S., Portz, A. (2016). Essential oil production of lemongrass (Cymbopogon citratus) under organic compost containing sewage sludge. Revista Brasileira de Engenharia Agricola E Ambiental, 20(9), 811-816.

29. Desai, M.A., Parikh, J. (2015). Extraction of essential oil from leaves of lemongrass using microwave radiation: optimization, comparative, kinetic, and biological studies. ACS Sustainable Chemistry and Engineering, 3(3), 421-431.

30. Diabate, S., Martin, T., Murungi, L.K., Fiaboe, K.K.M., Subramanian, S., Wesonga, J., Deletre, E. (2019). Repellent activity of Cymbopogon citratus and Tagetes minuta and their specific volatiles against Megalurothrips sjostedti. Journal of Applied Entomology, 143(8), 855-866.

31. Ekpenyong, C.E., Akpan, E.E., Daniel, A.E. (2014). Phytochemical constituents, therapeutic applications and toxicological profile of Cymbopogon citatus Stapf (DC) leaf extract. Journal of Pharmacognosy and Phytochemistry, 3(1), 133-141.

32. Ekpenyong, Ch.E., Akpan, E.E. (2017). Use of Cymbopogon citratus essential oil in food preservation: Recent advances and future perspectives. Critical Reviews in Food Science and Nutrition, 57(12), 2541-2559.

33. Falcao, M.A., Fianco, A.L.B., Lucas, A.M., Pereira, M.A.A., Torres, F.C., Vargas, R.M.F., Cassel, F. (2012). Determination of antibacterial activity of vacuum distillation fractions of lemongrass essential oil. Phytochemistry Reviews, 11(4), SI, 405-412.

34. Farias, P.K.S., Silva, J.C.R.L., de Souza, C.N., da Fonseca, F.S.A., Brandi, I.V., Martins, E.R., Azevedo, A.M., de Almeida, A.C. (2019). Antioxidant activity of essential oils from condiment plants and their effect on lactic cultures and pathogenic bacteria. Ciencia Rural, 49(2), art. no. e2018140.

35. Fernandes, S.S., Tonato, D., Mazutti, M.A., de Abreu, B.R., Cabrera, D.D., D'Oca, C.D.M., Prentice-Hernandez, C., Salas-Mellado, M.D. (2019). Yield and quality of chia oil extracted via different methods. Journal of Food Engineering, 262, 200-208.

36. FoodData Central [https://fdc.nal.usda.gov/]. Access date: 09.10.2019.

37. Frankova, A., Smid, J., Bernardos, A., Finkousova, A., Marsik, P., Novotny, D., Legarova, V., Pulkrabek, J., Kloucek, P. (2016). The antifungal activity of essential oils in combination with warm air flow against postharvest phytopathogenic fungi in apples. Food Control, 68, 62-68.

38. Ganjewala, D., Luthra, R. (2010). Essential oil biosynthesis and regulation in the genus Cymbopogon. Natural Product Communications, 5(1), 163-172.

39. Guenther, E. (1950). The essential oils, IV. D. Van Nostrad company. Inc., New York, USA, pp 20-65.

40. Guimarães de Lima, L.G., Cardoso das Graças, M., de Sousa, P.E., de Andrade, J., Vieira, S.S. (2011). Antioxidant and fungitoxic activities of the lemongrass essential oil and citral. Revista Ciência Agronômica, 42 (2), 464-472.
41. Hadjilouka, A., Mavrogiannis, G., Mallouchos, A., Paramithiotis, S., Mataragas, M., Drosinos, E.H. (2017). Effect of lemongrass essential oil on Listeria monocytogenes gene expression. LWT - Food Science and Technology, 77, 510-516.

42. Haloui, I., Meniai, A.H. (2017). Supercritical $\mathrm{CO}_{2}$ extraction of essential oil from Algerian Argan (Argania spinosa L.) seeds and yield optimization. International Journal of Hydrogen Energy, 42(17), 12912-12919.

43. Hanaa, A.R.M., Sallam, Y.I., El-Leithy, A.S., Aly, S.E. (2012). Lemongrass (Cymbopogon citratus) essential oil as affected by drying methods. Annals of Agricultural Sciences, 57(2), 113-116.

44. Haque, A.N.M.A., Ramadevi, R., Naebe, M. (2018). Lemongrass (Cymbopogon): a review on its structure, properties, applications and recent developments. Cellulose, 25(10), 5455-5477.

45. Harris, R. (2002) Progress with superficial mycoses using essential oils. International Journal of Aromatherapy, 12 (2), 83-91.

46. Hartanti, D., U1 Haqqi, M.Z., Hamad, A. (2018). Potency of combination of essential oils of ginger and lemongrass as fresh chicken meat natural preservative. Advanced Science Letters, 24(1), 91-94.

47. Hartatie, E.S., Prihartini, I., Widodo, W., Wahyundi, A. (2019). Bioactive compounds of lemongrass (Cymbopogon citratus) essential oil from different parts of the plant and distillation methods as natural antioxidantin broiler meat. IOP Conference Series: Materials Science and Engineering, 532, DOI: 10.1088/1757899X/532/1/012018.

48. Helal, G.A., Sarhan, M.M., Abu Shahla, A.N., Abou El-Khair, E.K. (2006). Effects of Cymbopogon citratus L. essential oil on the growth, lipid content and morphogenesis of Aspergillus niger ML2-strain. Journal of Basic Microbiology, 46(6), 456-469.

49. Jo, W.S., Song, H.Y., Song, N.B., Lee, J.H., Min, S.C., Song, K.B. (2014). Quality and microbial safety of 'Fuji' apples coated with carnauba-shellac wax containing lemongrass oil. LWT Food Science and Technology, 55(2), 490-497.

50. Kahramanoglu, I. (2019). Effects of lemongrass oil application and modified atmosphere packaging on the postharvest life and quality of strawberry fruits. Scientia Horticulturae, 256, art. no. 108527.

51. Kasali, A.A., Oyedeji, A.O., Ashilokun, A.O. (2001). Volatile leaf oil constituents of Cymbopogon citratus (DC) Stapf. Flavour and Fragrance Journal, 16(5), 377-378.

52. Kpoviessi, S., Bero, J., Agbani, P., Gbaguidi, F., Kpadonou-Kpoviessi, B., Sinsin, B., Accrombessi, G., Frederich, M., Moudachirou, M., Quetin-Leclercq, J. (2014). Chemical composition, cytotoxicity and in vitro antitrypanosomal and antiplasmodial activity of the essential oils of four Cymbopogon species from Benin. Journal of Ethnopharmacology, 151 (1), 652-659.

53. Kumar, V., Tewari, R., Singh, K. (2015). Comparative studies of drying methods on yield and composition of the essential oil of Cymbopogon citratus. Journal of Essential Oil Bearing Plants, 18(3), 744-750.

54. Kurita, N., Miyaji, M., Kurane, R., Takahara, Y. (1981). Antifungal activity of components of essential oils. Agricultural and Biological Chemistry, 45(4), 945-952.

55. Lawrence, R., Lawrence, K., Srivastava, R., Gupta, D. (2015). Antioxidant activity of lemon grass essential oil (Cymbopogon citratus) grown in North Indian plains. The Scientific Temper, 4, 23-29. 
56. Leite, J.R., Delourdes, M., Seabra, V., Maluf, E., Assolant, K. Suchecki, D., Tufik, S., Klepacz, S., Calil, H.M., Carlini, E.A. (1986). Pharmacology of lemongrass (Cymbopogon citratus Stapf). III. Assessment of eventual toxic, hypnotic and anxiolytic effects on humans. Journal of Ethnopharmacology, 17(1), 75-83.

57. Leite, M.C.A., de Brito Bezerra, A.P., de Sousa, J.P., de Oliveira Lima, E. (2015). Investigating the antifungal activity and mechanism(s) of geraniol against Candida albicans strains. Medical Mycology, 53(3), 275-284.

58. Leite, M.C.A., de Brito Bezerra, A.P., de Sousa, J.P., Guerra, F.Q.S., de Oliveira Lima, E. (2014). Evaluation of antifungal activity and mechanism of action of citral against Candida albicans. Evidence-Based Complementary and Alternative Medicine, 2014, art. no. 378280.

59. Lu, M., Han, Z., Yao, L. (2013). In vitro and in vivo antimicrobial efficacy of essential oils and individual compounds against Phytophthora parasitica var. nicotianae. Journal of Applied Microbiology, 115(1), 187-198.

60. Mani-López, E.M., Valle-Vargas, G.P., Palou, E., López-Malo, A. (2018). Penicillium expansum inhibition on bread by lemongrass essential oil in vapor phase. Journal of Food Protection, 81(3), 467-471.

61. Mansour, A.F., Fikry, R.M., Saad, M.M., Mohamed, A.M (2015). Chemical composition, antioxidant and antimicrobial activity of (Cymbopogon citratus) essential oil cultivated in Madinah Monawara, Saudi Arabia and its comparison to the Egyptian chemotype. International Journal of Food and Nutritional Sciences, 4(4), 29-33.

62. Marongiu, B., Piras, A., Porcedda, S., Tuveri, E. (2006). Comparative analysis of the oil and supercritical $\mathrm{CO}_{2}$ extract of Cymbopogon citratus Stapf. Natural Product Research, 20(5), 455-459.

63. Matasyoh, J.C., Wagara, I.N., Nakavuma, J.L, Kiburai, A.M. (2011). Chemical composition of Cymbopogon citratus essential oil and its effect on mycotoxigenic Aspergillus species. African Journal of Food Science, 5(3), 138-142.

64. Mbili, N.C., Opara, U.L., Lennox, C.L., Vries, F.A. (2017). Citrus and lemongrass essential oils inhibit Botris cinerea on 'Golden Delicious', 'Pink Lady' and 'Granny Smith' apples. Journal of Plant Diseases and Protection, 124(5), 499-511.

65. Mirghani, M.E.S., Liyana, Y., Jamal, P. (2012). Bioactivity analysis of lemongrass (Cymbopogan citratus) essential oil. International Food Research Journal, 19(2), 569-575.

66. Mith, H., Dure, R., Delcenserie, V., Zhiri, A., Daube, G., Clinquart, A. (2014). Antimicrobial activities of commercial essential oils and their components against food-borne pathogens and food spoilage bacteria. Food Science and Nutrition, 2(4), 403-416.

67. Moore-Neibel, K., Gerber, C., Patel, J., Friedman, M., Ravishankar, S. (2012). Antimicrobial ectivity of lemongrass oil against Salmonella enterica on organic leafy greens. Journal of Applied Microbiology, 112(3), 485-492.

68. Moutassem, D., Belabid, L., Bellik, Y., Ziouche, F.B. (2019). Efficacy of essential oils of various aromatic plantsin the biocontrol of Fusarium wilt and inducing systemic resistance in chickpea seedlings. Plant Protection Science, 55(3), 202-217.

69. Murmu, S.B., Mishra, H.N. (2018). The effect of edible coating based on Arabic gum, sodium caseinate and essential oil of cinnamon and lemon grass on guava. Food Chemistry, 245, 820-828.
70. Naik, M.I., Fomda, B.A., Jaykumar, E., Bhat, J.A. (2010). Antibacterial activity of lemongrass (Cymbopogon citratus) oil against some selected pathogenic bacterias. Asian Pacific Journal of Tropical Medicine, 3(7), 535-538.

71. Nguefack, J., Tamgue, O., Dongmo, J.B.L., Dakole, C.D., Leth, V., Vismer, H.F., Zollo, P.H.A., Nkengfack, A.E. (2012). Synergistic action between fractions of essential oils from Cymbopogon citratus, Ocimum gratissimum and Thymus vulgaris against Penicillium expansum. Food Control, 23(2), 377-383.

72. Nikaido, H. (2003). Molecular basis of bacterial outer membrane permeability revisited. Microbiology and Molecular Biology Review, 67(4), 593-656

73. Olorunnisola, S.K., Asiyanbi, H.T., Hammed, A. M., Simsek, S. (2014). Biological properties of lemongrass: An overview. International Food Research Journal, 21 (2), 455-462.

74. Onawunmi, G.O., Yisak, W.A., Ogunlana, E.O. (1984). Antibacterial constituents in the essential oil of Cymbopogon citratus (D.C) Stapf. Journal of Ethnopharmacology, 12 (3), 279-286.

75. Pereira F.D.O., Mendes, J.M., Lima, I.O., Mota, K.S.D., de Oliveira, W.A., Lima E.D, O. (2015). Antifungal activity of geraniol and citronellol, two monoterpenes alcohols, against Trichophyton rubrum involves inhibition of ergosterol biosynthesis. Pharmaceutical Biology, 53(2), 228-234.

76. Perez, G.S., Zavala, S.M., Garcia, A.L., Ramos, L.M. (2011). Anti-inflammatory activity of some essential oils. Journal of Essential Oil Research, 23(5), SI, 38-44.

77. Premathilake, U.G.A.T., Wathugala, D.L., Dharmadasa, R.M. (2018). Evaluation of chemical composition and assessment of antimicrobial activities of essential oil of lemongrass (Cymbopogon citratus (DC.) Stapf. International Journal of Minor Fruits, Medicinal and Aromatic Plants, 4(1), 13-19.

78. Reis-Teixeira, F.B., Sousa, I.P., Alves, F.V., Cardoso Furtado, N.A.J.C., De Martinis, E.C.P. (2019). Evaluation of lemongrass and ginger essential oils to inhibit Listeria monocytogenes in biofilms. Journal of Food Safety, 39(4), art. no. e12627.

79. Reyes-Jurado, F., Navarro-Cruz, A.R., Ochoa-Velasco, C.E., Palou, E., Lopez-Malo, A., Avila-Sosa, R. (2019). Essential oils in vapor phase as alternative antimicrobials: A review. Critical Reviews in Food Science and Nutrition, DOI: 10.1080/10408398.2019.1586641.

80. Roriz, C.L., Barros, L., Carvalho, A.M., Santos-Buelga, C. Ferreira, I.C.F.R. (2014). Pterospartum tridentatum, Gomphrena globosa and Cymbopogon citratus: A phytochemical study focused on antioxidant compounds. Food Research International, 62, 684-693.

81. Santin, M.R., dos Santos, A.O., Nakamura, C.V., Dias, B.P., Ferreira, I.C.P., Ueda-Nakamura, T. (2009). In vitro activity of the essential oil of Cymbopogon citratus and its major component (citral) on Leishmania amazonensis. Parasitology Research, 105(6), 1489-1496.

82. Schaneberg, B.T., Khan, I.A. (2002). Comparison of extraction methods for marker compounds in the essential oil of lemon grass by GC. Journal of Agricultural and Food Chemistry, 50(6), $1345-1349$.

83. Shaikh, M.N., Suryawanshi, Y.Ch., Mokat, D.N. (2019). Volatile profiling and essential oil yield of Cymbopogon citratus (DC.) Stapf treated with rhizosphere fungi and some important fertilizers. Journal of Essential Oil Bearing Plants, 22(2), 477-483. 
84. Sharma, A., Rajendran, S., Srivastava, A., Sharma, S., Kundu, B. (2017). Antifungal activities of selected essential oils against Fusarium oxysporum f. sp. lycopersici 1322, with emphasis on Syzygium aromaticum essential oil. Journal of Bioscience and Bioengineering, 123(3), 308-313.

85. Shi, C., Song, K., Zhang, X., Sun, Y., Sui, Y., Chen, Y., Xia, X. (2016). Anti-microbial activity and possible mechanism of action of citral against Cronobacter sakazakii. PLoS One, 11(7), art. no. e0159006.

86. Sidibé, L., Chalchat, J.C., Garry, R.P., Lacombe, L., Harama, M. (2001). Aromatic plants of Mali (IV): chemical composition of essential oils of Cymbopogon citratus (DC) Stapf and C. giganteus (Hochst.) Chiov. Journal of Essential Oil Research, 13(2), 110-112.

87. Sinha, S., Jothiramajayam, M., Ghosh, M., Mukherjee, A. (2014). Evaluation of toxicity of essential oils palmarosa, citronella, lemongrass and vetiver in human lymphocytes. Food and Chemical Toxicology, 68, 71-77.

88. Skaltsa, H.D., Demetzos, C., Lazari, D., Sokovic, M. (2003). Essential oil analysis and antimicrobial activity of eight Stachys from Greece. Phytochemistry, 64(7), 743-752.

89. Skaria, B.P., Joy, P.P., Mathew, G., Mathew, S., Joseph, A. (2012). Lemongrass. In K.V. Peter (Ed.), Handbook of Herbs and Spices, vol. 2, 2nd edition, Woodhead Publ. LTD, Abington Hall Abington, Cambridge CB1 6AH, Cambs, England, vol. 228, pp. 348-370.

90. Smith, R.L., Cohen, S.M., Doull, J. (2005). GRAS flavouring substances 22. Food Technology, 59(8), 24-62.

91. Sonker, N., Pandey, A.K., Singh, P.,Tripathi, N.N. (2014). Assessment of Cymbopogon citratus (DC.) Stapf essential oil as herbal preservatives based on antifungal, antiaflatoxin, and antiochratoxin activities and in vivo efficacy during storage. Journal of Food Science, 79(4), M628-M634.

92. Soonwera, M., Phasomkusolsil, S. (2016). Effect of Cymbopogon citratus (lemongrass) and Syzygium aromaticum (clove) oils on the morphology and mortality of Aedes aegypti and Anopheles dirus larvae. Parasitology Research, 115(4), 1691-1703.

93. Sousa, S.M., Silva, P.S., Viccini, L.F. (2010). Cytogenotoxicity of Cymbopogon citratus (DC) Stapf (lemon grass) aqueous extracts in vegetal test systems. Anais Da Academia Brasileira De Ciencias, 82(2), 305-311.

94. Suryawanshi, M.A., Mane, V.B., Kumbhar, G.G. (2016). Methodology to extract essential oils from lemongrass: solvent extraction approach. International Research Journal of Engineering and Technology, 3(8), 1775-1780.

95. Tajidin, N.E., Ahmad, S.H., Rosenani, A.B., Azimah, H., Munirah, M. (2012). Chemical composition and citral content in lemongrass (Cymbopogon citratus) essential oil at three maturity stages. African Journal of Biotechnology, 11 (11), 2685-2693.

96. Tapsell, L.C., Hemphill, I., Cobiac, L., Patch, C.S., Sullivan, D.R., Fenech, M., Roodenrys, S., Keogh, J.B., Clifton, P.M., Williams, P.G., Fazio, V.A., Inge, K.E. (2006). Health benefits of herbs and spices: the past, the present, the future. Medical Journal of Australia, 185(4), S4-S24.
97. Tavares, F., Costa, G., Francisco, V., Liberal, J., Figueirinha, A., Lopes, M.C., Cruz, M.T., Batista, M.T. (2015). Cymbopogon citratus industrial waste as a potential source of bioactive compounds. Journal of the Science of Food and Agriculture, 95(13), 2652-2659.

98. Tran, T.H., Nguyen, D.C., Ph, T.N.N, Ho, V.T.T., Vo, N.D.V., Bach, L.G., Nguyen, T.D. (2019). Research on lemongrass oil extraction technology (hydrodistillation, microwave-assisted hydrodistillation). Indonesian Journal of Chemistry, 19(4), in press, DOI: 10.22146/ijc.40883.

99. Tyagi, A.K., Gottardi, D., Malik, A., Guerzoni, M.E. (2014). Chemical composition, in vitro anti-yeast activity and fruit juice preservation potential of lemon grass oil. $L W T$ - Food Science and Technology, 57(2), 731-737.

100. Tzortzakis, N.G., Economakis, C.D. (2007). Antifungal activity of lemongrass (Cymbopogon citratus L.) essential oil against key postharvest pathogen. Innovative Food Science and Emerging Technologies, 8(2), 253-258

101. Vasireddy, L., Bingle, L.E.H., Davies, M.S. (2018). Antimicrobial activity of essential oils against multidrug-resistant clinical isolates of the Burkholderia Cepacia complex. PLoS One, 13(8), art. no. e0201835.

102. Vazirian, M., Kashani, S.T., Ardekani, M.R.S., Khanavi, M., Jamalifar, H., Fazeli, M.R., Toosi, A.N. (2012). Antimicrobial activity of lemongrass (Cymbopogon citratus (DC) Stapf.) essential oil against food-borne pathogens added to cream-filled cakes and pastries. Journal of Essential Oil Research, 24(6), 579-582.

103. Verma, R.K., Verma, R.S., Chauhan, A., Bisht, A. (2015). Evaluation of essential oil yield and chemical composition of eight lemongrass (Cymbopogon spp.) cultivars under Himalayan region. Journal of Essential Oil Research, 27(3), 197-203.

104. Viuda-Martos, M., El Gendy, A.E.N.G.S., Sendra, E., Fernandez-Lopez, J., El Razik, K.A.A., Omer, E.A., Perez-Alvarez, J.A. (2010). Chemical composition and antioxidant and antiListeria activities of essential oils obtained from some Egyptian plants. Journal of Agricultural and Food Chemistry, 58(16), 9063-9070.

105. Wu, H., Li, J., Jia, Y., Xiao, Z., Li, P., Xie, Y., Zhang, A., Liu, R., Ren, Z., Zhao, M., Zeng, Ch., Li, Ch. (2019). Essential oil extracted from Cymbopogon citronella leaves by supercritical carbon dioxide: antioxidant and antimicrobial activities. Journal of Analytical Methods in Chemistry, art. no. 8192439.

106. Yen, H.Y., Lin, Y.C. (2017). Green extraction of Cymbopogon citrus essential oil by solar energy. Industrial Crops and Products, 108, 716-721.

107. Zaki, E.F., Nadir, A.A., Helmy, I.M.F., Maguid, N.M.A. (2018). Antioxidant and antimicrobial effects of lemongrass (Cymbopogon citrates) oil on the quality characteristics of camel burger "Camburger" under refrigerated storage. International Journal of Current Microbiology and Applied Sciences, 7(3), 3623-3631.

108. Zhou, H., Tao, N., Jia, L. (2014). Antifungal activity of citral, octanal and $\alpha$-terpineol against Geotrichum citri-aurantii. Food Control, 37, 277-283.

Submitted: 23 July 2019. Revised: 26 September and 11 October 2019. Accepted: 17 October 2019. Published on-line: 7 November 2019. 